\title{
TO THE QUESTION OF MOTIVATION IN TEACHING FOREIGN LANGUAGES TO THE STUDENTS OF TECHNICAL SPECIALITIES: PSYCHOLOGICAL AND PEDAGOGICAL ASPECT
}

\author{
N. V. YAREMENKO, PhD in Pedagogy, Associate Professor, \\ National University of Life and Environmental Sciences of Ukraine \\ E-mail: iaremenko.nv@gmail.com \\ orcid.org/0000-0002-5894-0295
}

\begin{abstract}
In the modern society, in the era of European integration processes, the status of a foreign language as a subject is changing. Taking into account the increasing interest to a foreign language as a means of communication, the modern methodology focuses on achieving higher results. One of the key elements of the language learning is the motivation of students to study this subject.

Accordingly, the purpose of the publication is to summarize the constituent elements of motivation while learning English. It has been established that the motivational aspect is crucial for the activation of all psychological processes of intellectual activity: thinking, perception of information, understanding and analyzing of knowledge, learning the material, developing dialogical and monological speaking. The reasons for students' high motivation to dialogical speaking (communication on various topics, a large number of creative tasks that make the classes interesting) are identified. It has been found that the creation of positive motivation to learn a foreign language is facilitated by the creation of psychological comfort during the organization of the educational process (atmosphere of good will in class, hand-holding to students, conversations on interesting and modern topics). Based on the analysis of scientific literature, several approaches to the teaching a foreign language (behavioral, inductive and conscious, cognitive, integrated) can be distinguished.
\end{abstract}

Keywords: motivation, psychological and pedagogical aspect, students, technical specialities, English.

Introduction. One of the hallmarks of modern day focused on globalization is the importance of individual knowledge of foreign languages. Learning English is particularly preferred at this stage. This professional and communicative needs require not only language skills but also the presence of existing skills and abilities to use the language in everyday life and communication [3, p. 56]. Formation of appropriate skills among future professionals is one of the most important tasks of the educational process of modern higher education. With the experience we have seen that it is almost impossible to do without the motivation of students to use the foreign language.

Analysis of recent researches and publications has showed that the problems of motivating students to learn foreign languages have been studied in the scientific literature. In particular, the question of psychological motivation of learning foreign languages is highlighted in the works of A. Alhazishvili, I. Zymniaia, A. Leontiev, N. Simonova

(C) N. V. Yaremenko

«International journal of philology» | «Міжнародний філологічний часопис» Vol. 10, № 3, 2019 


\section{Issues in theory and methods of teaching foreign languages \\ Проблеми теорії і методики навчання іноземних мов}

and others. Psychological principles of the use of foreign languages in the formation of future specialists and ways to overcome the uncertainty in their own abilities revealed in the works of $\mathrm{S}$. Tsymbal. Ways to increase motivation to study foreign languages have been considered by A. Kotova, N. Lyeshniova and others.

However, in our opinion, it is necessary to summarize the components of the motivational component while learning English, which is the purpose of the study.

Methods and materials of research. During the research the method of analysis of scientific literature for understanding the motivational component while learning English and coverage of approaches to teaching in terms of psychology has been used. For the study a significant number of fundamental works on this issue and the latest publication of the abovementioned problems were used.

Results. In today's society, in the era of European integration processes, the status of a foreign language as an academic subject is changing and increasing. In view of the growing importance of foreign language as a means of communication in the world community, the current methodology is primarily aimed at achieving more tangible results of language learning.

Experience has shown that learning is effective and productive only when students have a positive motivation to learn a foreign language, and the formation of aspects such as a person's willingness and ability to develop new ideas, new technologies and their practical implementation, is not possible without a psychological approach to the student's personality.

The motivational aspect is crucial for the activation of all psychological processes inherent in intellectual activity thinking, perception of information, understanding and analysis of acquired knowledge, assimilation of foreign language material, the development of dialogic and monologic speech.

Thus, S. Tsymbal emphasizes that dialogic speech is always motivated, because during it students learn to communicate on different topics, absorbing not only linguistic units and grammatical constructions, but also part of the culture of the language being taught. Significant motivation for dialogic speech is due to a large selection of interesting creative tasks, which include:

- interviews;

- business game;

- role play;

- discussion;

- information exchange;

- round table;

- debates, etc.

The researcher emphasizes that in the process of role communication students exert some influence on the role played, in a certain way influencing the personality, since losing the role of emotionally sensual, sensitive, tactful and friendly person, the student may feel a taste of kindness and sensitivity, to want to relive again this feeling [8, p. 299].

Therefore, mental and physical experiences and personality needs, as well as a conscious internal or external need, are important for the motivation of learning a foreign language for a future specialist. The presence of motivation to use a foreign language stimulates the development of language skills, thinking, and arouses the desire to learn more and learn to think in a foreign language. In this way, the formation of motivation satisfies the needs of the individual in the formation of appropriate skills and

(C) N. V. Yaremenko

«International journal of philology» | «Міжнародний філологічний часопис» Vol. 10, № 3, 2019 


\section{Issues in theory and methods of teaching foreign languages \\ Проблеми теорії і методики навчання іноземних мов}

abilities, as well as creates positive attitudes for learning a foreign language.

Along with the formation of motivation as a major psychological factor in the study of a foreign language by future specialists of non-linguistic specialties, it is of great importance to maintain psychological comfort during the organization of the educational process. To do this, the teacher must:

- create an atmosphere of goodwill in the classroom;

- explain that making mistakes is natural, the main thing is to have the desire to try to avoid them by acquiring new knowledge, skills and abilities;

- support students;

- organize conversations on topics that are of great interest to students;

- plan classes selecting those exercises and activities that are of interest to students and not to read and translate texts on specific purpose.

Thus, the types of work that are of great interest to students and create a welcoming atmosphere for learning on the one hand, and on the other involving students in active work, are Round Robin, Timed Pair Share, Inside-Outside Circle, Find Someone Who, Pairs Compare, Find-the-Fiction [7, p. 45; 9, p. 105].

These psychological aspects of foreign language learning by students of non-linguistic faculties are inextricably linked to the teaching methodology and strategy of approach to the organization of the educational process. Based on the analysis of the scientific literature, there are several approaches to teaching a foreign language. Namely, the modern domestic methodology traditionally relies on four common learning strategies, an integral part of which is compliance with the conditions of psychological comfort and the formation of motivation in students:
- behavioral approach;

- inductive and conscious approach;

- cognitive approach;

- integrated approach.

The close interaction of "stimulus" and "reaction" is in the basis of the behavioral approach. The main task of training is to develop skills through intensive training, the quality of which is directly linked to psychologically comfortable learning conditions. Motivation is of secondary importance.

The inductive and conscious approach is based on intensive practical work on numerous examples, which gradually leads to mastering language rules and linguistic actions.

Cognitive approach is realized in the mastering of the elements of theory, which is achieved as a result of work on the study of the rules of phonetics, grammar, vocabulary. In keeping with this approach, the motivation for learning a foreign language is at the forefront. An integrated approach is implemented in the combination of conscious and subconscious components of the learning structure $[1 ; 2 ; 4 ; 6]$.

However, in recent decades, methodologists, psychologists, and teachers have increasingly emphasized the appropriateness of using a differentiated approach to learning and using a foreign language, which, in their view, is driven primarily by the existence of psychologically different types of personality. This, in turn, corresponds to the personal approach to the education of future specialists, which is central to the higher education system nowadays [6, $p$. 32].

The effectiveness of the implementation of a differentiated approach is a prerequisite for identifying, first of all, psychological factors for improving the methodology of teaching a 
foreign language, which, by the definition of G.E. Vedel, has many contradictions and ambiguous aspects.

Accordingly, the interaction of different scientific approaches and directions is the foreground, since the methodology of teaching foreign languages does not exist in isolation, it is connected with a number of other sciences (philosophy, physiology, psychology, linguistics, pedagogy, etc.) and relies on the established ones. regularities. However, there are many problems that can be solved only with psychology and physiology, or based on psychological and physiological patterns [2, p. 4].

The main aspect, which must always be kept in mind when improving the teaching of a foreign language, should be the provision that mastering a foreign language first means learning how to think in that language. This justification implies a joint search by teachers and students of the means of overcoming psychological barriers that impede the acquisition of a foreign language $[1, p$. 15].

All of the above puts forward the dominant importance of psychology in the development of foreign language teaching techniques. Nowadays, considerable theoretical material has been accumulated in psychology, as well as regularities that influence the level of mastering and mastering a foreign language. As an example, the regularities highlighted by G. E Vedel:

\section{Список використаних джерел}

1. Артемов В. А. Психология обучения иностранным языкам. Москва: Просвещение, 1969. 279 с.

2. Ведель Г. Е. Очерк методики преподавания немецкого языка. Воронеж: Изд-во Воронежского
- theory of unity of consciousness and activity;

- theory of gradual formation of thought processes;

- theory of installation;

- the concept of an open and hidden way of learning;

- theory of the degree of intensity of students' excitement in the learning process;

- the concept of internal speech, etc. [2, p. 115].

Conclusions and research prospects. Thus, the use of learning a foreign language is the interaction between teachers and future professionals, primarily because any learning process in their psychological nature is a joint activity of all participants. The task of the teacher is the psychological management of cognitive activity of future specialists, forming their motivation and focus on practice and skills formation using a foreign language. Implementing and maintaining psychological factors in learning vocabulary will expand the circle of linguistic and geographical knowledge, range of language activities related to communication with native foreign language. It should be noted the fact that psychological factors improve the process of learning a foreign language as a whole can not contribute to the development and improvement of linguistic, geographic and communicative competence of future specialists.

ун-та, 1976. 218 с.

3. Верещагин Е. М., Костомаров В. Г. Язык и культура: Лингвострановедение в преподавании русского языка как иностранного: метод. руководство. - 3-е изд перераб. и доп. Москва : Русский язык, 2003.

(C) N. V. Yaremenko

«International journal of philology» | «Міжнародний філологічний часопис» Vol. 10, № 3, 2019 
$1038 \mathrm{c}$.

4. Есипович К. Б. Управление познавательной деятельностью учащихся при изучении иностранных языков в средней школе. Москва: Просвещение, 1988.190 с.

5. Ковалев А.Г. Личность и ее направленность. Психология. 2006. № 3. С.331-366.

6. Ляховицкий М. В. О некоторых базисных категориях методики обучения иностранным языкам. Общая методика обучения иностранным языкам. 1991. С. 28 - 38.

7. Михеева Н. Ф. Методика преподавания иностранных языков: учеб. пособие. 2-е изд., испр. и доп. Москва : РУДН, 2010. 76 с.

8. Ц Цимбал С. В. Психологічні засади використання іноземної мови у процесі формування майбутніх спеціалістів. Актуальні проблеми психології: Проблеми психології творчості: Збірник наукових праць. 2009. № 7. T. 12. C. $296-302$

9. Tsymbal S. Overcoming Language Anxiety among the English Language Learners: Psycho-Pedagogical Aspect. Science and Education. 2017. № 7. C. $102-106$

\section{References}

1. Artemov, V. A. (1969). Psykholohyia obuchenyia ynostrannim yazikam [Psycology of Foreign language Learning]. Prosveshchenye, 279.

2. Vedel, H. E. (1976). Ocherk metodyky prepodavanyia nemetskoho yazika. [Outlines how to Teach the German Language ]. Yzd-vo un-ta, 218

3. Vereshchahyn, E. M., Kostomarov, V. H. (2003). Yazik i kultura: Lynhvostranovedenye $v$ prepodavanyy russkoho yazika kak inostrannoho
[Language and Culture. Culture-throughLanguage Studies when teaching Russian as a Foreign language]. Moscow, Russia: the Russian Language, 1038.

4. Esypovych, K. B. (1988). Upravlenye poznavatelnoi deiatelnostiu uchashchykhsia pry yzuchenyy inostrannskh yazikov $v$ srednei shkole [Management of students' learning activity when teaching foreign languages in secondary schools]. Moscow, Russia: Education, 190.

5.Kovalev, A. H. (2006). Lychnost i ee napravlennost [Personality and his/her orientation]. Psykholohyia, 3, 331-366.

6. Liakhovytskyi, M. V. (1991). O nekotorikh bazysnikh katehoryiakh metodiky obuchenyia inostrannim yazikam [To some Basic Categories of foreign Language Teaching Methods]. Obshchaia metodyka obuchenyia inostrannim yazikam, $28-38$.

7. Mykheeva. N. F. (2010). Metodyka prepodavanyia inostrannikh yazikov [Methods of Foreign Language Teaching]. Moscow: RUDN, 76.

8. Tsymbal S. V. (2009). Psykholohichni zasady vykorystannia inozemnoi movy u protsesi formuvannia maibutnikh spetsialistiv [Phycological Principles of Usage of a Foreign Language when Training Specialists-toBe]. Aktualni problemy psykholohii: Problemy psykholohii tvorchosti, 7 (12), 296- 302.

9.Tsymbal S. (2017). Overcoming Language Anxiety among the English Language Learners: Psycho-Pedagogical Aspect. Science and Education, 7, $102-$ 106. 
Issues in theory and methods of teaching foreign languages

Проблеми теорії і методики навчання іноземних мов

\title{
ДО ПИТАННЯ МОТИВАЦІЇ ПРИ ВИКЛАДАННІ ІНОЗЕМНОЇ МОВИ СТУДЕНТАМ ТЕХНІЧНИХ СПЕЦІАЛЬНОСТЕЙ: ПСИХОЛОГО-ПЕДАГОГІЧНИЙ АСПЕКТ Н.В. Яременко
}

\begin{abstract}
Анотація. У сучасному суспільстві, в епоху загальноєвропейських інтеграційних процесів змінюється $і$ зростає статус іноземної мови як навчального предмету. 3 огляду на посилення значення іноземної мови як засобу спілкування і порозуміння у світовому співтоваристві, сучасна методика передусім спрямована на досягнення більш відчутних результатів вивчення мови. Одним із ключових елементів ефрективного навчання є мотивація студентів до вивчення навчальної дисципліни. Отже, метою публікації $\epsilon$ узагальнення складових мотивації під час вивчення англійської мови. Установлено, що мотиваційний аспект має вирішальне значення для активізації всіх психологічних процесів, притаманних інтелектуальній діяльності - мислення, сприйняття інфоомації, розуміння та аналізу отриманих знань, засвоєння іншомовного матеріалу, розвитку діалогічного та монологічного мовлення. Виявлено причини високої мотивації студентів до діалогічного мовлення (спілкування на різні теми, велика кількість творчих завдань, що роблять заняття цікавим). З'ясовано, що створенню позитивної мотивації сприяє створення психологічного комфорту під час організації освітнього процесу (атмосфрера доброзичливості на занятті; підтримка студентів, організація бесід на цікаві та сучасні теми тощо). На основі аналізу наукової літератури можна виділити декілька підходів до викладання іноземної мови (біхевіористський, індуктивно-свідомий, пізнавальний, інтегрований).Установлено, що створенню позитивної мотивації сприяє комплексне застосування зазначених підходів, враховуючи рівень знань студентів та їх психологічні особливості).
\end{abstract}

Ключові слова: мотивація, психолого-педагогічний аспект, студенти, технічні спеціальності, англійська мова.

(C) N. V. Yaremenko

«International journal of philology» | «Міжнародний філологічний часопис» Vol. 10, № 3, 2019 